\title{
Prevalence and Some Correlates of Child Marriage in Kapilbastu District, Nepal
}

\author{
Dhanendra Veer Shakya, PhD \\ Central Department of Population Studies, Tribhuvan University, Kirtipur, Nepal \\ Corresponding Author \& Email \\ Dhanendra Veer Shakya; Email: shakyadv@gmail.com \\ Article History \\ Submitted 18 August 2021; Reviewed 7 September 2021; Accepted 16 September 2021 \\ DOI: https://doi.org/10.3126/ajps.v1i1.43591
}

\section{Copyright Information: \\ Copyright 2022@ The Author(s). \\ The journal is licensed under a \\ Creative Commons Attribution- \\ ShareAlike 4.0 International \\ License.

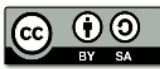 \\ Published by \\ Department of Population Studies \\ Prithvi Narayan Campus \\ Tribhuvan University \\ Pokhara, Nepal}

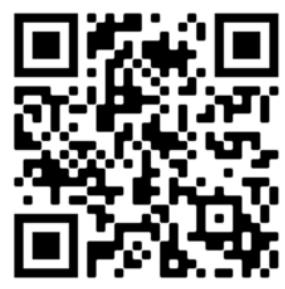

Scan to Access eJournal

\section{Abstract}

The study was carried out to examine the prevalence of child marriage before ages 20 and 18 , some correlates of early marriage and prevalence of early birth as its consequence in Kapilbastu district, Nepal. The correlates of child marriage of young people (10-24 years), especially that of females were examined with some selected variables like caste/ethnicity, wealth status of household, ruralurban place of residence and education of young females. The study has used the data files of Child Marriage Baseline Survey 2016. The findings of the study are presented in percentages in cross tabulations and charts and significance of data is tested using chi-square with degrees of freedom from the contingency tables of frequency distribution at $\mathrm{p} \leq 0.001, \mathrm{p} \leq 0.01$ and $\mathrm{p} \leq 0.05$ levels. The study found significantly higher proportion of young females than males marrying for the first time before ages $20(23.6 \%$ vs. $9.6 \%, \mathrm{p}<0.001)$ and $18(16.6 \%$ vs. $5.9 \%, \mathrm{p}<0.001)$. The prevalence of girl's marriage before age 20 is higher among certain caste/ethnic groups like 'other' category (36.8\%), Dalits (31.9\%), Terai/Madheshi $(29.6 \%)$ castes. The findings are also significant at $p<0.001$ from the contingency table of frequency distribution according to caste/ethnicity. More females living in the rural area than in urban were marred before ages $20(26 \%$ vs. $19 \%)$ and $18(19.8 \%$ vs. $10.3 \%)$. However, the data is not found significant at $\mathrm{p}=0.05$ level. Similarly, the association between wealth status of household and early marriage was also not found significant at $\mathrm{p}=0.05$ level. There is found negative association between age at first marriage of young females and level of their education, except for primary level of education, as the proportions of young females 


\section{Prevalence and Some Correlates of Child Marriage in Kapilbastu District, Nepal}

marrying before ages 20 and 18 declined with the increased level of education from no formal education $(40.5 \%$ and $29.7 \%$ respectively) to secondary level $(26.1 \%$ and $20.7 \%$ respectively) to higher than secondary level (15.1\% and $1.9 \%$ respectively). The results are also significant at $\mathrm{p}<0.001$ level. The major and immediate consequences of early marriage are early pregnancy and childbirth. More than one-third females aged 20-24 years who married before 18 years of age, had given birth to a child before age 20 and one-in-ten had a birth within the first year of marriage.

Keywords: Child marriage, early marriage, age at first marriage, young people (10-24 years), before age 20 , and before age 18

\section{Introduction}

Child marriage is a common practice in many societies and it is associated with structural and socio-cultural factors. The structural factors comprise the legal and policy frameworks relating to the protection of the adolescents. The inaccessibility to quality services, such as schools, health, and social welfare, lower economic opportunities, poor infrastructure and communication isolating certain groups from wider social networks, poverty, conflicts and natural disasters can attribute the prevalence of child marriage. Likewise, discriminatory socio-cultural practices against particular groups, including girls and women, and the gender roles restricting girls and women to family and household responsibilities, dowry and bride price practices, family honour and, chastity beliefs and importance of arranged marriages, and lack of awareness of alternatives to early marriage lead to girl child marriage (CDPS, 2017b).

It has been recognized that child marriage is a serious problem against the violation of girls' human rights, resulting in a hindrance to national development by national and international communities. A considerable amount of studies has identified a number of root causes and key drivers of child marriage (UNICEF Nepal, \& Girls-notBride Nepal, 2015; Lee-Rife, Malhotra, Warner, \& Glinski, 2012). Although these drivers are of context-specific, poverty is one of the major factors underpinning early marriage. Evidence suggests that impoverished families regard a young girl as an economic burden, and securing her marriage, therefore, enables the family to transfer the responsibility of caring for her to others (UNICEF, 2001). The daughters' marriage helps their parents relieve the financial burden of subsistence and education. Some families prefer their daughters' early marriage to avoid the rising cost of dowry or the decreasing value of bride-wealth, or to avoid the risk of a possible mismatch of a suitable spouse later in life.

Since gender-based discriminations are highly attached to the virginity and chastity of a girl, the families are obliged to place a high value on female's virginity through the early marriage of their daughters. In some contexts, girls who remain unmarried for too long may face the scrutiny of their chastity and may risk damaging their and the family's reputation (Gaffney-Rhys, 2011). Similarly, the compensation strategy of the labour shortage in the family chores may also lead the parents to marry their sons with virgin girls causing a child marriage. Studies have claimed an increasing trend of the school teenagers falling in love and escaping away from the school (Adhikari, 2016) as a burgeoning social problem. Child marriage in Nepal often stems from the family's perception of girls as a burden. Such a burden can be associated with the dowry system and the early marriage can be a response to minimize the expenditure in the form of dowry.

The social and economic value of girls in the family and the society relates to their ability to care for the household needs of the family, suitability as a bride and childbearing. In such context, child marriage is common. These social and gender 


\section{Prevalence and Some Correlates of Child Marriage in Kapilbastu District, Nepal}

expectations are also realized through besides others, early marriage and coincide with early and frequent childbearing. The married girls are confined to the roles of bringing up children and managing domestic chores are generally left out with less alternative options. Therefore, child marriage is perceived as a social norm and practice in many societies with a belief to get the girls married before they are an adult (CDPS, 2017b).

The prevalence of child marriage before age 18 among population aged 20-24 years was 22.7 per cent in 2019 in Nepal (32.8\% women and 9\% men) and that before age 15 was 5.2 per cent ( $7.9 \%$ women and $1.5 \%$ men) (CBS, 2020). The corresponding figures in Lumbini Province of Nepal where Kapilbastu is located were higher compared to the national average with 25 per cent $(33.7 \%$ women and $11.4 \%$ men) and 6.4 per cent (8.9\% women and $2.4 \%$ men) respectively. Similarly, the percentage of married population aged 15-19 in 2019 in Nepal was 12.8 (19.3\% women and 5.3\% men) and that in Lumbini was 13.9 per cent $(20.1 \%$ women and $6.3 \%$ men), a higher than the national average in this case also.

Early childbearing is one of the consequences of early marriage. The percentage of women aged 20-24 years who have had a live birth before age 18 was 13.8 in 2019 in Nepal, whereas the figure for Lumbini was little less than the national average with 12.6 per cent (CBS, 2020). Likewise, the adolescent birth rate of 15-19 years in Nepal was 63 per 1,000 women and that for Lumbini was 57 per 1,000 women in 2019.

\section{Objectives of the study}

The study has attempted to examine the prevalence of child marriage in Kapilbastu district of Nepal; its perspective reasons; relationships, if there is any, between some selected socio-economic variables and early marriage; and prevalence of early birth as a consequence of early marriage. So, the study has made some efforts to fulfil the gap in available information in the selected area in these issues. Child marriage or early marriage in this study is considered as marriage before ages 18 and 20 years in two different scenarios. The following are the objectives of the study:

1. To estimate the prevalence of child marriage before ages 20 and 18 for both females and males,

2. To examine correlates between early marriage of young people and some selected variables like caste/ethnicity, wealth status, rural-urban place of residence and education of young females,

3. To explore the reasons for early marriage, and the prevalence of early birth as a consequence of early marriage.

\section{Data and Methods}

A study carried out by UNICEF Nepal and Girls-not-Bride Nepal (2015) had identified Kapilbastu as one of the six most child marriage prevalent districts in Nepal. Thus, Kapilbastu was selected for purpose of the study relating to child marriage issues. Both rural and urban areas of the district along with population of different caste/ethnicity and diverse wealth status were covered in the study.

The data used in this study is secondary in nature. The data sources are the data files of Child Marriage Baseline Survey 2016 conducted by Central Department of Population Studies, Tribhuvan University, Nepal. Kapilbastu was one of the five districts of Nepal covered by the survey.

This is a cross-sectional study with research designs of both correlational and descriptive types and based on quantitative data. The study was based on sample survey of both household and individual levels. Individuals were young female population of 10-24 years of age. 


\section{Prevalence and Some Correlates of Child Marriage in Kapilbastu District, Nepal}

Twenty-two clusters of enumeration areas were selected based on probability proportional to size of households at the level of the former village development committee and municipality of the district with each cluster comprising 20 households. The households were selected using systematic random sampling method from the selected clusters of wards or sub-wards of the former village development committee and municipality. Thus, altogether 440 households were selected from the 10 village development committees and municipality of Kapilbastu for the purpose of the study. The selected village development committees and municipality of Kapilbastu were Basnkhore, Nandanagar, Lawani, Bithuwa, Hathihawa, Sisuwa, Hardauna, Shivpur and Pathardaiya village development committees, and Kapilbastu municipality. In the selected households, married and unmarried girls and boys aged between 10 and 24 years were the primary target population of the study.

The survey tools for data collection were a set of two different structured questionnaires viz. household schedule an individual schedule. The household schedule was administered to the heads of households and individual schedule to young female population aged 10-24 years for collecting information regarding child marriage from the selected households. The data was collected using face to face interview with the household heads and young female population.

The structured questionnaires as research instruments and its contents were designed incorporating the concerned issues relating to early marriage. It was thoroughly reviewed by the subject experts and feedbacks were considered. Before finalizing the instruments, it was pre-tested and improved and modified accordingly. Field researched who collected the information was trained intensively making them familiar with the purpose and theme of the each and every content of the instruments.

The data were analysed and presented in percentages in the forms of cross tables as well as in charts. Statistical significance tests of contingency tables were carried out using chi-square tests.

The study has attempted to maintain the basic research ethics, including prior approval on its methodology and survey instruments from National Health Research Council (NHRC), informed consent of participants for their voluntary participation and ensured them about use of the collected information only in categorical groups but not at individual level.

\section{Anticipated Outputs}

The study has anticipated outputs of estimation of prevalence rate of child marriage before 20 and 18 years of age for both males and females aged 10-24 years in Kapilbastu district of Nepal. The major reasons for early marriage of girl children from the perspective of household heads are also expected to explore. Associations between some selected variables like caste/ethnicity, wealth status, rural-urban place of residence and education of young females with early marriage and estimation of prevalence rate of early birth as a consequence of early marriage is also anticipated to examine.

\section{Prevalence and some selected correlates of child marriage Marital status of young people}

The proportion of married young people (10-24 years) in the study area of Kapilbastu district of Nepal was 28 per cent among females, including those who were married but not having Gauna ${ }^{l}$. The girls who marry at early ages stay in their parent's

1 Gauna is the traditional practices existed in Terai/Madheshi community. In family's consent girls and boys get married at early ages (before 10 or 12), and groom side leave the bride in her maternal 


\section{Prevalence and Some Correlates of Child Marriage in Kapilbastu District, Nepal}

house until their Gauna is completed. As far as males are concerned, the proportion of married young males was slightly more than 13 per cent (Figure1) including those who were married but their wife not having Gauna. The chi-square value of 34.5 with degree of freedom two for the contingency table of frequency distribution of young males and females according to marital status is found to be significant at $\mathrm{p}<0.001$ level. Therefore, the difference between proportions of married young males and females was remarkable and it showed that more girls than boys get married at early ages.

\section{Figure 1}

Percentage distribution of young people (10-24 years) by gender and marital status

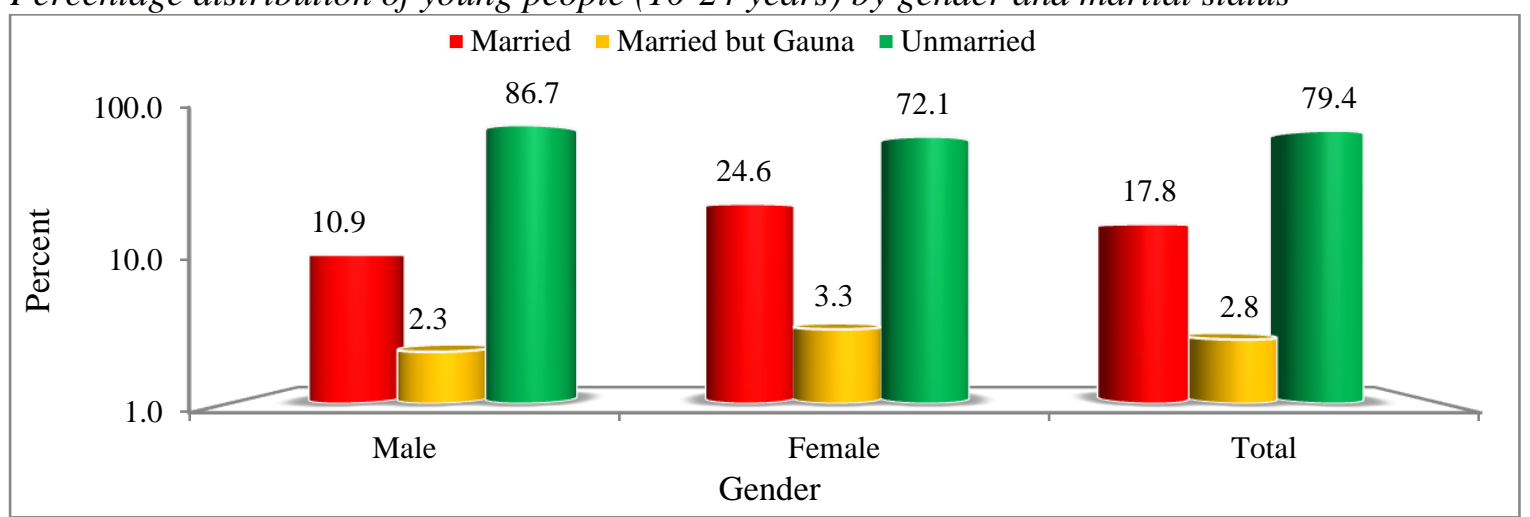

Note: The results are statistically significant at $p<0.001$ level.

\section{Prevalence of child marriage}

More than 16 per cent young people were found married before age 20 for the first time in Kapilbastu (Figures 2) with a significantly higher proportion of females than males (23.6\% vs. $9.6 \%$ ), as chi-square value of 36.4 along with degree of freedom one for the contingency table of frequency distribution of young males and females marrying before age 20 is found to be significant at $p<0.001$ level. Likewise, the study also found that more than 16 per cent young females and 6 per cent young males were married before age 18 (Figures 3). The chi-square value of 29.5 along with degree of freedom one for the contingency table of frequency distribution of young males and females marrying before age 18 is also found to be significant at $p<0.001$ level. This indicates a higher prevalence of girls getting married at early ages than boys and suggests that the practice of an early age marriage among girls in Nepali society is still prevalent.

home until she grow mature (15+ years). Then, both sides decide a day to arrange bride-sending ceremony to groom's house like as second marriage. This bride sending and taking groom's home ceremony is called as Gauna. 


\section{Prevalence and Some Correlates of Child Marriage in Kapilbastu District, Nepal}
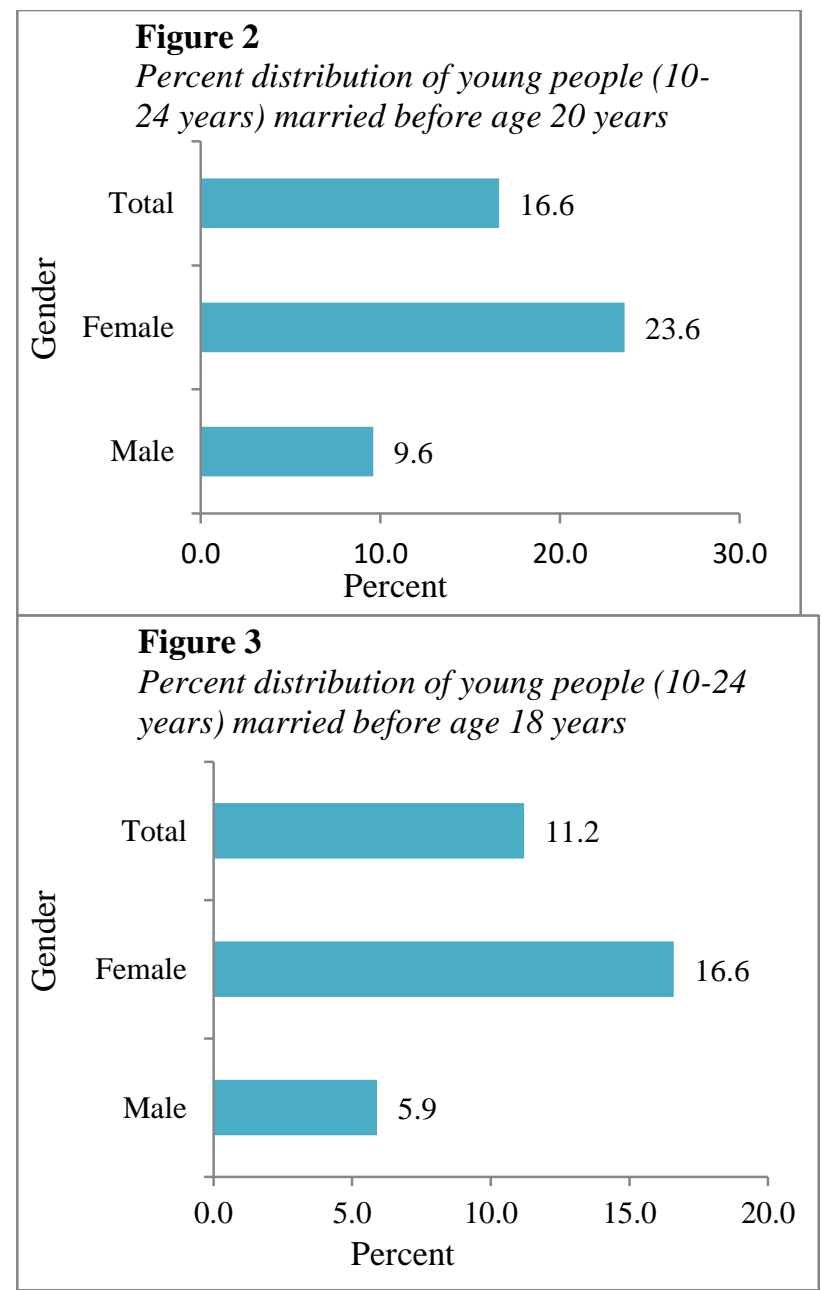

Note: The results are statistically significant at $p<0.001$ level.

\section{Some selected factors associated with child marriage}

This study is confined only to a few variables like caste/ethnicity, wealth quintile, rural-urban residence and education of young females for linking with an early marriage of young people (10-24 years) to observe association between them. Among certain caste/ethnic groups like 'other' category which included unidentified castes not listed in National Population Census 2011, Dalits and Terai/Madheshi castes, the prevalence of girl's marriage before age 20 is higher $(36.8 \%, 31.9 \%$ and $29.6 \%$ respectively) compared to rest of other caste/ethnic groups (Table 1). It was also higher among Muslim (14.6\%) and Janajati (15.2\%) girls marrying before age 20 compared to Brahmin/Chhetri (6.8\%). The chi-square value of 24.9 with degree of freedom 5 for the contingency table of frequency distribution of young females marrying before age 20 according to caste/ethnic group, is found to be significant at $p<0.001$ level.

However, it was not observed any influence of wealth quintile in age at first marriage of girls. Because for girls marrying before age 20, the chi-square value of 4.3 with degree of freedom 3 for the contingency table of frequency distribution of young females marrying before age 20 according to wealth quintile is not found significant at $\mathrm{p}=0.05$ level. More females living in the rural area than in urban were marred before age $20(26 \%$ vs. $19 \%)$. However, the difference was not found statistically significant as the chi-square value of 3.1 with degree of freedom one for the contingency table of 


\section{Prevalence and Some Correlates of Child Marriage in Kapilbastu District, Nepal}

frequency distribution of young females marrying before age 20 according to rural-urban place of residence, is not found significant at $\mathrm{p}=0.05$ level. The patterns are almost similar by the selected factors of young females who married before 20 and 18 years of ages and the same can be said for young male population as well with the similar results obtained from the statistical significance tests also.

Table 1

Percentage distribution of young people (10-24 years) married before ages 20 and 18 years according to castelethnicity, wealth quintile and rural-urban residence

\begin{tabular}{|l|l|l|l|l|l|l|l|l|l|l|}
\hline \multirow{2}{*}{ Selected variables } & \multicolumn{3}{|l|}{ Male married at } & \multicolumn{3}{l|}{ Female married at } & \multicolumn{3}{|c|}{ Total married at } \\
\cline { 2 - 10 } & $<20$ & $<18$ & Cotal (n) & $<20$ & $<18$ & otal (n) & $<20$ & $<18$ & otal (n) \\
\hline Caste/ethnicity*** & & & & & & & & & \\
Brahman/Chhetri & 0.0 & 0.0 & 43 & 6.8 & 2.3 & 44 & 3.4 & 1.1 & 87 \\
Terai/Madheshi castes & 14.4 & 9.8 & 153 & 29.6 & 22.8 & 162 & 22.2 & 16.5 & 315 \\
Dalits & 14.8 & 6.8 & 88 & 31.9 & 22.3 & 94 & 23.6 & 14.8 & 192 \\
Janajati & 5.0 & 1.3 & 80 & 15.2 & 11.4 & 79 & 10.1 & 9.4 & 159 \\
Muslim & 2.9 & 2.9 & 103 & 14.6 & 8.3 & 96 & 8.5 & 7.5 & 199 \\
Other & 15.6 & 11.1 & 45 & 36.8 & 23.7 & 38 & 25.3 & 12.0 & 83 \\
Wealth quintile & & & & & & & & & \\
Poorest & - & - & - & - & - & - & - & - & - \\
Poor & 0.0 & 0.0 & 5 & 0.0 & 0.0 & 8 & 0.0 & 0.0 & 13 \\
Middle & 4.4 & 2.2 & 45 & 20.0 & 8.9 & 45 & 12.2 & 5.6 & 90 \\
Rich & 12.9 & 7.6 & 132 & 27.8 & 21.5 & 144 & 20.7 & 14.9 & 276 \\
Richest & 9.1 & 5.8 & 330 & 22.8 & 15.8 & 316 & 15.8 & 10.7 & 646 \\
Rural-urban residence & & & & & & & & & \\
Rural & 11.4 & 7.4 & 352 & 26.0 & 19.8 & 339 & 18.5 & 13.5 & 691 \\
Urban & 5.6 & 2.5 & 160 & 19.0 & 10.3 & 174 & 12.6 & 6.6 & 334 \\
\hline Total & 9.6 & 5.9 & 512 & 23.6 & 16.6 & 513 & 16.6 & 11.2 & 1,025 \\
\hline
\end{tabular}

$* * *$ Statistically significant at $\mathrm{p}<0.001$ level.

Source: Data files of Child Marriage Baseline Survey 2016 (CDPS, 2017a).

Other category of caste/ethnic group includes unidentified castes not listed and categorized as 'other' in National Population Census 2011.

There appears to be a remarkable association between age at first marriage of young females and level of education. The proportions of young females marrying before age 20 and 18 decreased with the increased level of education, except for primary level of education. More than 40 per cent young females were married before age 20 among those who don't have any formal education, it was 26 and 15 per cent among those whose have secondary and higher than secondary levels of education respectively (Figure 4). The chi-square value of 27.4 with degree of freedom 3 for the contingency table of frequency distribution of young females marrying before age 20 according to educational level, is found to be significant at $\mathrm{p}<0.001$ level. Likewise, the proportions marrying before age 18 was nearly 30 per cent among those who don't have any formal education and it was about 21 and only two per cent among those whose have secondary and higher than secondary levels of education respectively. In this case also, the chisquare value of 26.9 with degree of freedom 3 for the contingency table of frequency distribution of young females marrying before age 18 according to educational level, is found to be significant at $p<0.001$ level. 


\section{Prevalence and Some Correlates of Child Marriage in Kapilbastu District, Nepal}

\section{Figure 4}

Per cent distribution of young females (10-24 years) married before age 20 and 18 by level of education

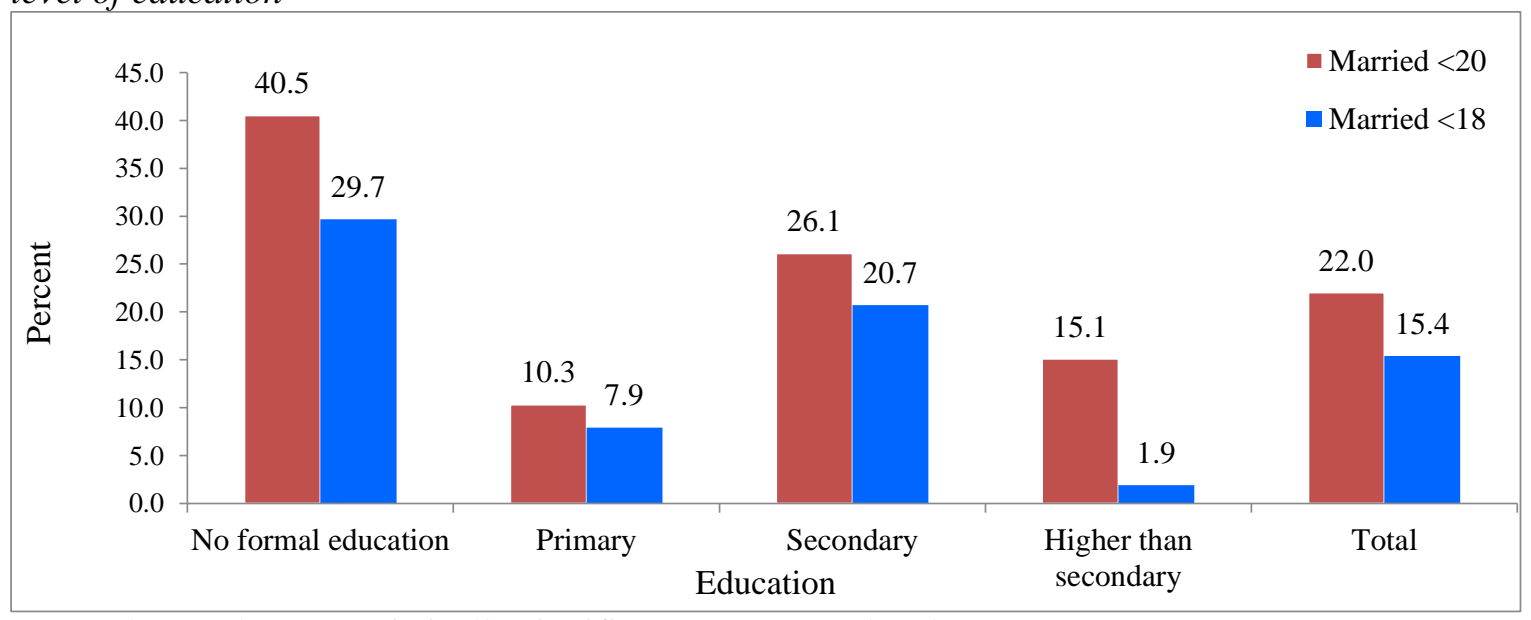

Note. The results are statistically significant at $\mathrm{p}<0.001$ level.

\section{Reason for early marriage}

The study revealed that the 'socio-cultural and religious practice' was the main reason for early marriage. Other two prominent reasons were 'offer came from good family/not asking heavy dowry/low marriage cost' and self-initiated love affair for early marriage. The social, cultural and religious practice was the reason for about 60 per cent young females to get married before age 20, and 'offer came from good family/not asking heavy dowry/low marriage cost' and self-initiation love affair were the reasons for another 15 per cent and over 12 per cent of them respectively. The corresponding figures for young males were 63 per cent, 16 per cent and 8 per cent respectively. Therefore, the first reason is predominant for both young men and women, particularly for females. The other reasons were reported by less than 10 per cent of household heads (Table 2).

Table 2

Percentage distribution of young people (10-24 years) marrying before age 20 by reason for early marriage as reported by household head

\begin{tabular}{|l|l|l|l|}
\hline Reason for early marriage & Male & Female & Total \\
\hline $\begin{array}{l}\text { Social, culture \& religious } \\
\text { practices }\end{array}$ & 63.3 & 59.5 & 60.6 \\
\hline $\begin{array}{l}\text { Offer from good family/not } \\
\text { asking heavy dowry/low } \\
\text { marriage cost }\end{array}$ & 16.3 & 14.9 & 15.3 \\
\hline Support in household work & 6.1 & 5.8 & 5.9 \\
\hline Love affair & 8.2 & 12.4 & 11.2 \\
\hline Other & 6.1 & 7.4 & 7.1 \\
\hline
\end{tabular}

Source: Data files of Child Marriage Baseline Survey 2016 (CDPS, 2017a).

Other reason includes weak in study/failed in school, would be difficult to get married in higher ages, due to family prestige, to avoid unwanted relationship between youngsters, to avoid outsider's gossips, and thinking that marriage may bring him/her in track.

'Socio-cultural and religious practice' was the main reason for early marriage of young females for almost all caste/ethnic groups in Kapilbastu district, except for Janajati, as the proportion of young females marrying before age 20 ranged between 47 


\section{Prevalence and Some Correlates of Child Marriage in Kapilbastu District, Nepal}

to 71 per cent among these caste/ethnic groups. 'Offer came from good family/not asking heavy dowry/low marriage cost' was also equally prime reason among Muslim community $(47 \%)$ for early marriage of young females, while and self-initiated love affair was the major reason for early marriage among Janajati. The social, cultural and religious practice was the sole prime reason for early marriage among households of different wealth quintiles and rural-urban place of residence (Table 3).

\section{Table 3}

Percentage distribution of young people (10-24 years) marrying before age 20 by reason responded by household head for early marriage according to castelethnicity, wealth quintile and rural-urban residence

\begin{tabular}{|c|c|c|c|c|c|}
\hline \multirow[t]{2}{*}{ Selected variables } & \multicolumn{5}{|c|}{ Reason for early marriage } \\
\hline & $\begin{array}{l}\text { Social, } \\
\text { culture \& } \\
\text { religious } \\
\text { practices }\end{array}$ & $\begin{array}{l}\text { Offer came from } \\
\text { good family/not } \\
\text { asking heavy } \\
\text { dowry/low } \\
\text { marriage cost }\end{array}$ & $\begin{array}{l}\text { Support } \\
\text { in } \\
\text { househol } \\
\text { d work }\end{array}$ & $\begin{array}{l}\text { Love } \\
\text { affair }\end{array}$ & Pther \\
\hline Caste/ethnicity & & & & & \\
\hline Brahman/Chhetri & 66.7 & 0.0 & 0.0 & 33.3 & 0.0 \\
\hline $\begin{array}{l}\text { Terai/Madheshi } \\
\text { castes }\end{array}$ & 71.4 & 10.0 & 2.9 & 4.3 & 11.4 \\
\hline Dalits & 65.1 & 14.0 & 9.3 & 7.0 & 4.7 \\
\hline Janajati & 18.8 & 0.0 & 6.2 & 62.5 & 12.5 \\
\hline Muslim & 47.1 & 47.1 & 5.9 & 0.0 & 0.0 \\
\hline Other & 57.1 & 23.8 & 9.5 & 9.5 & 0.0 \\
\hline Wealth quintile & & & & & \\
\hline Poorest & - & - & - & - & - \\
\hline Poor & - & - & - & - & - \\
\hline Middle & 54.5 & 0.0 & 0.0 & 27.3 & 18.2 \\
\hline Rich & 54.4 & 12.3 & 8.8 & 12.3 & 12.3 \\
\hline Richest & 64.7 & 18.6 & 4.9 & 8.8 & 2.9 \\
\hline $\begin{array}{l}\text { Rural-urban } \\
\text { residence }\end{array}$ & & & & & \\
\hline Rural & 51.6 & 19.5 & 6.2 & 13.3 & 9.4 \\
\hline Urban & 88.1 & 2.4 & 4.8 & 4.8 & 0.0 \\
\hline Total & 60.6 & 15.3 & 5.9 & 11.2 & 7.1 \\
\hline
\end{tabular}

Source: Data files of Child Marriage Baseline Survey 2016 (CDPS, 2017a).

Other category of caste/ethnic group includes unidentified castes not listed and categorized as 'other' in National Population Census 2011.

\section{Early birth as a consequence of early marriage}

In Nepal, girls and women are under pressure to have a baby shortly after their marriage. This serves to prove their fertility. Consequently, one of the major and immediate consequences of early marriage is early pregnancy and childbirth. Among female respondents aged 20-24 years and married before 18 years of age in Kapilbastu, more than one-third (39.4\%) had given birth to a child before age 20 and one-in-ten $(9.1 \%)$ had a birth within the first year of marriage (Figure 5). 


\section{Prevalence and Some Correlates of Child Marriage in Kapilbastu District, Nepal}

\section{Figure 5}

Per cent distribution of female respondents who gave birth before ages 20 among aged 20-24 years and marrying before age 18

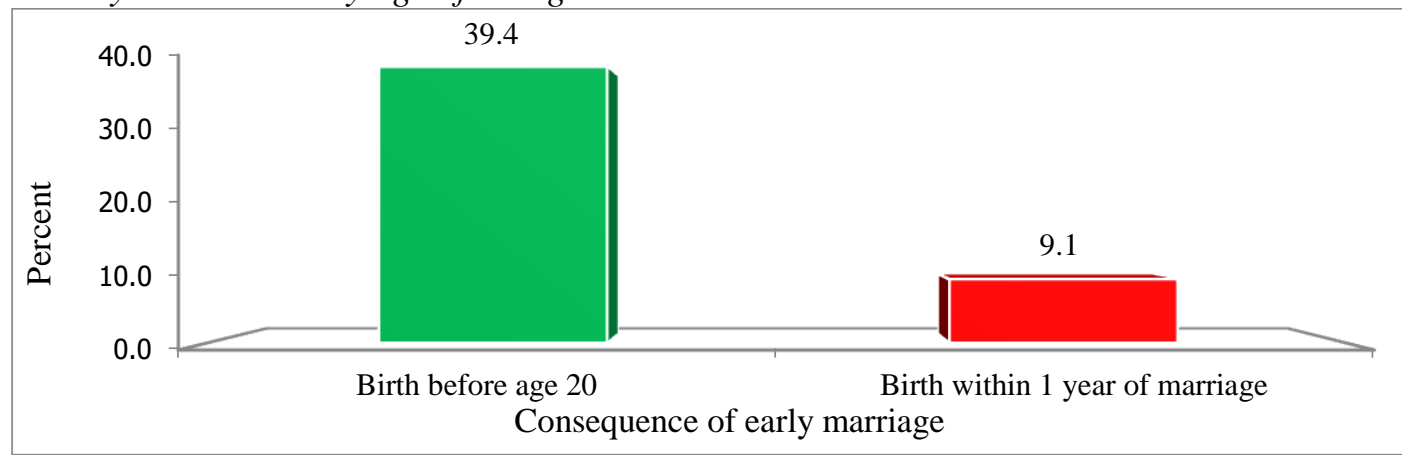

The higher percentage of Janajati young females (80\%) had given births to a child before 20 years of age followed by Terai/Madhesi castes (43.8\%), Muslim (33.3\%) and Dalits (12.5\%) in Kapilbastu (Table 4). The corresponding figure was one-half among urban females aged 20-24 years who married before age 18 and 37 per cent among their rural counterparts. But it was found declined as wealth quintile of household improved from middle (75\%) to rich $(45.5 \%)$ and then to richest $(27.8 \%)$.

\section{Table 4}

Per cent distribution of female respondents who gave birth before ages 20 among aged 20-24 years and marrying before age 18 according to castelethnicity, wealth quintile and rural-urban residence

\begin{tabular}{|c|c|c|}
\hline Selected variables & Birth before age 20 & $\begin{array}{l}\text { Birth within } 1 \text { year of } \\
\text { marriage }\end{array}$ \\
\hline \multicolumn{3}{|l|}{ Caste/ethnicity } \\
\hline Brahman/Chhetri & - & - \\
\hline Terai/Madheshi castes & 43.8 & 6.2 \\
\hline Dalits & 12.5 & 12.5 \\
\hline Janajati & 80.0 & 20.0 \\
\hline Muslim & 33.3 & 0.0 \\
\hline Other & 0.0 & 0.0 \\
\hline \multicolumn{3}{|l|}{ Wealth quintile } \\
\hline Poorest & - & - \\
\hline Poor & - & - \\
\hline Middle & 75.0 & 50.0 \\
\hline Rich & 45.5 & 0.0 \\
\hline Richest & 27.8 & 5.6 \\
\hline \multicolumn{3}{|l|}{ Rural-urban residence } \\
\hline Rural & 37.0 & 7.4 \\
\hline Urban & 50.0 & 16.7 \\
\hline Total & 39.4 & 9.1 \\
\hline
\end{tabular}

Source: Data files of Child Marriage Baseline Survey 2016 (CDPS, 2017a).

Other category of caste/ethnic group includes unidentified castes not listed and categorized as 'other' in National Population Census 2011.

As in the case of giving births to a child before 20 years of age, higher per cent of Janajati females $(20 \%)$ had given births to a child within one year of their marriage. It was 12.5 per cent among Dalit females and 6.2 per cent among community of 


\section{Prevalence and Some Correlates of Child Marriage in Kapilbastu District, Nepal}

Terai/Madhesi castes. Similarly, the figure was one-half among females of middle wealth quintile and only 5.6 per cent among richest, but none among rich. But more urban females than their rural counterparts in Kapilbastu (16.7\% vs. $7.4 \%)$ had given births to a child within one year of their marriage.

One of the severe consequences of child marriage as observed in the field is that mothers and daughters get pregnant at the same time and give a birth at the same time. There was ample evidence of mother above age 30 with her last pregnancy and her first daughter with the first pregnancy. However, the paradox is that mothers were victims of child marriage because of the early marriage arranged by the parents and the daughter's own choices of teenage love.

\section{Discussion and Conclusion}

It is a cultural practice in many communities in Nepal that girls marry at an early age compared to boys and it was observed in Kapilbasu also. The difference between prevalence of married young males and females aged 10-24 years was remarkable (28\% vs. $13 \%)$ with statistically significant as well $(p<0.001)$ indicating that more girls than boys get married at early ages. A significantly higher proportion of young females than males were married for the first time before ages 20 and 18 (23.6\% vs. 9.6\% and $16.6 \%$ vs. $5.9 \%$ respectively). These figures were also found statistically significant at $\mathrm{p}<0.001$ level.

Early marriage especially among women can be influenced by socio-cultural and religious factors among others. Difference in cultural practices of different caste/ethnic groups of people in the society, can have influence on early marriage. The study observed that among certain caste/ethnic groups like Terai/Madheshi castes (29.6\%), Dalits $(31.9 \%)$ and 'other' category (36.8\%), the prevalence of girl's marriage before age 20 is higher compared to rest of other caste/ethnic groups. The prevalence was also higher among Muslim (14.6\%) and Janajati (15.2\%) girls marrying before age 20 compared to Brahmin/Chhetri $(6.8 \%)$. The prevalence of early marriage according to different caste/ethnic groups of people were also found statistically significant at $\mathrm{p}<0.001$ level. The wealth status of household may be an attributing factor for early or late marriage of an individual because it can inspire for acquiring educational level besides other. So, it was expected to be one of the influencing factors before conducting the study. However, the wealth status of household in the study area was not found influencing for early marriage. Similarly, rural-urban place of residence was also expected to be one of the factors affecting early marriage. Because of relatively easy access to different opportunities in urban areas than in rural, it may contribute to late marriage in some extents. The study also observed more females living in the rural area than in urban marred before ages 20 and 18 (26\% vs. $19 \%$ and $19.8 \%$ vs. $10.3 \%$ respectively). But the differences were not found to be statistically significant at $\mathrm{p}=0.05$ level.

Education is one of the most important factors that influence many other factors including age at marriage and it has been observed in many past studies. There is also found association between age at first marriage of young females and level of education in the study area. The proportions of young females marrying before age 20 decreased with the increased level of their education, except for primary level of education, from 40.5 per cent for no formal education to 26.1 per cent for secondary level to 15.1 per cent for higher than secondary level of education. Likewise, it for marrying before age 18 decreased from 29.7 per cent for no formal education to 20.7 per cent for secondary level to 1.9 per cent for higher than secondary level of education. In both the cases, the findings are statistically significant at $p<0.001$ level. 


\section{Prevalence and Some Correlates of Child Marriage in Kapilbastu District, Nepal}

The reasons for early marriage of young people may be curious issues to explore behind its causes. So, the study has also examined the reasons for early marriage of young people from the perspectives of household heads as there may be different reasons for it. 'Socio-cultural and religious practice' was the main reason for early marriage as it was reported by the household heads for every 6 in 10 young females marrying before age 20 . The other two important reasons were 'offer came from good family/not asking heavy dowry/low marriage cost' $(15.3 \%)$ and self-initiated love affair $(11.2 \%)$ for early marriage.

One of the major and immediate consequences of early marriage is early pregnancy and childbirth. The study has also examined the prevalence of early childbirth on the basis of birth before age 20 and birth within one year of marriage. The study showed that among females aged 20-24 years and married before 18 years of age, more than one-third had given birth to a child before age 20 and one-in-ten had a birth within the first year of marriage. The higher percentage of Janajati young females $(80 \%)$ had given births to a child before 20 years of age followed by Terai/Madhesi castes (43.8\%), Muslim (33.3\%) and Dalits with the least percentage of 12.5. As the wealth quintile of household improved from middle to rich and then to richest, the consequences of child marriage in the form of a child birth before age 20 seemed declined from 75 per cent to 45.5 per cent then to 27.8 per cent respectively. Likewise, more Janajati females (20\%) than other caste/ethnic groups had given births to a child within one year of their marriage followed by Dalit community (12.5\%) of Terai/Madhesi castes (6.2\%).

\section{References}

Adhikari, K.P. (2016). Impact of earthquake on child labour in the earthquake affected districts: A study of Ramechhap, Kavrepalanchwok and Bhaktapur districts. A report submitted to Child Development Society (CDS) and Save the Children (SC) Nepal. Kathmandu: CDC and SC-Nepal.

Central Bureau of Statistics (CBS). (2020). Nepal Multiple Indicator Cluster Survey 2019, Survey findings report. Kathmandu: CBS and UNICEF Nepal.

Central Department of Population Studies (CDPS), Tribhuvan University (TU). (2017a). Data files of Child Marriage Baseline Survey 2016. Kathmandu: CDPS, TU. (2017b). Situation assessment of child marriage in selected five intervention districts of Nepal. Kathmandu: CDPS, TU.

Lee-Rife, S., Malhotra, A., Warner, A., \& Glinski, A.M. (2012). What works to prevent child marriage? A review of the evidence. Studies in family planning, 43(4), 287303. URL: http://www.jstor.org/stable/23409224

Gaffney-Rhys, R. (2011). International law as an instrument to combat child marriage, The international journal of human rights, 15(3), 359-373. https://doi.org/ 10.1080/13642980903315398

UNICEF-Nepal and Girls-not-Bride Nepal. (2015). National strategy to end child marriage in Nepal: Formative research. Kathmandu: UNICEF and Girls not Bride Movement.

UNICEF. (2001). Early marriage: Child spouse, Innocenti digest, 7, 1-28. 